and purifying it to hecogenin acetate. Production and marketing of the chick sexer and aural microscope are proceeding satisfactorily.

Of the 664 inventions communicated to the Cor poration during the year, 268 were from government departments and research councils, 50 from Common. wealth official organizations, 18 from industrial research associations, 38 from universities and 269 from British firms and individuals. The rights of 375 patents and patent applications were assigned to the Corporation during the year, of which 315 were from government departments and research councils, 14 from industrial research associations, 30 from universities and 8 from British firms and individuals. The Corporation now holds some 2,647 United Kingdom and overseas patents and patent applications, and, of the 272 licence agreements with industry in force, 99 were revenue-earning, producing $£ 27,650$ during the year.

\section{CENTRAL LABORATORIES FOR SCIENTIFIC AND INDUSTRIAL RESEARCH, HYDERABAD \\ REPORT FOR 1953}

$\mathrm{T}$

HE annual report* for 1953 of the Central Laboratories for Scientific and Industrial Research, Hyderabad, stresses the increasing number of postgraduate students - twenty-two were working in the Laboratories for their Ph.D. in 1953-as evidence of the increasing concribution of the Laboratories both in training and in scientific and technical research. The research staff now numbers fifty-eight, and the report lists twenty-five papers published during the year, apart from forty communicated to the forty-first Indian Science Congress, held at Hyderabad in 1954.

In the Oils Section of the Laboratories, work was carried out on local bleaching earths, and on the preparation of dehydrated castor oil giving completely tack-free films and of alkyd resins modified by castor oil. The solubility and effectiveness of aca-catechin and katha-catechin as antioxidants in ghee were studied, the separation of fatty acid mixtures by adduct formation with urea was shown to be a much simpler method than conventional methods, and a suitable method was worked out for refining cotton-seed oil on a cottage-industry basis. The Entomology Section continued its studies of the toxicity of the seed oil from Annona squamosa (sitaphal) to vertebrates, and this oil appears to be fungistatic rather than fungicidal to Helminthosporium (paddy). The Paper Section was placed on a semi-commercial scale, and good progress was made in the manufacture of drawing paper and bond paper. In the Fuel Section the erection of the 12 ton/day ovoid briquetting plant was completed and the plant put into operation; experiments on binders for low-temperature tar continued. Further work was carried out on the distillation of lowtemperature tar, the solvent extraction of tar acids and hydrocarbons from coal tar oils, and on benzole recovery from the low-temperature carbonization gas, while a systematic survey of the coalfields of Hyderabad commenced in July 1953.

* Central Laboratories for Scientiflc and Industrial Research, Central Laboratories for Scientific and Industrial Research, 1954.)
The Heavy Chemicals and Fertilizers Section was occupied with the utilization of felspar (including studies of bricks from felspar sludge and on the influence of silica on the recovery of potash by the calcination process) and of iron pyrites (including the preparation of manganese dithionate, manganous sulphate and sulphur), the preparation of activated charcoal from teak-wood sawdust and from groundnut hulls, and the thermal decomposition of manganese sulphate and calcium sulphate to produce sulphur dioxide. The Ceramics Section made a systematic study of Hyderabad clays and the preparation of fireclay refractories from such clays. Investigations on potential synthetic analgesics in the Organic Chemistry, Pharmaceuticals and Drugs Section covered compounds of the quinazoline type and a new synthesis of pethidine. Studies on Indian turpentine included the preparation of a chlorinated product which was highly toxic to various insect tests, and work on the synthesis of menthol. In the work on compounds with œstrogenic activity, stilbene com. pounds were obtained by condensation of 3-chlorobutanone with phenol or its ethers in presence of sulphuric acid or anhydrous aluminium chloride, but the reaction is not general for $\alpha$-halogeno ketones. 'The synthesis of 'Vanitrope' (2-ethoxy-5-propenylphenol) is being attempted and also the preparation of fine chemicals from fusel oil, while a series of ketones obtained by condensing lævulinic acid with aromatic aldehydes are being examined as plant growth regulators.

The Biochemistry Section has given its attention chiefly to the fermentation of pre-treated molasses to citric acid, to itaconic acid fermentation, to oxidations by Pseudomonas fluorescens and to the nitrogenous constituents of the seed cake of Annona squamosa. In the X-ray Section, X-ray studies were made of Hyderabad and Indian clays, while the Physical Chemistry Section investigated the conductivity of sulphuric acid in aqueous acetone and ethyl alcohol and the titration of tartaric acid with potassium dichromate. Besides the erection of the 25-ton/day low-temperature carbonization pilot plant, the Chemical Engineering Section completed work on the saturation solubilities of groundnut oil and cottonseed oil in aqueous ethyl alcohol and was further equipped with pilot-plant items for cottonseed processing, vacuum distillation and the manufacture of synthetic resins.

\section{IMPERIAL COLLEGE OF SCIENCE AND TECHNOLOGY, LONDON}

\section{REPORT FOR 1953-54}

$T$ HE forty-seventh annual report of the governing body of the Imperial College of Science and Technology, London, covering the year ended July $31,1954^{*}$, gives some details of the immediate proposals for expansion. Licences have already been granted for the erection of an additional story over the Goldsmiths' Company's extension to the City and Guilds College and the Royal School of Mines building, the first part of the extension of the chemical engineering building and the addition of two stories to the Union building. In January this

* Imperial College of Science and Technology. Forty-seventh Annual Report of the Governing Body, 1953-1954. Pp. 65. (London: Imperial College of Science and Technology, 1955.) 